\title{
DISTRIBUTION OF FROZEN-THAWED SPERMATOZOA IN THE REPRODUCTIVE TRACT OF GILTS AT DIFFERENT TIME INTERVALS AFTER INSEMINATION
}

\author{
S. EINARSSON AND S. VIRING \\ Department of Obstetrics and Gynaecology and \\ Department of Clinical Biochemistry, Royal Veterinary College, \\ S-104 05 Stockholm 50, Sweden
}

(Received 11th Fuly 1972)

\begin{abstract}
Summary. The distribution of spermatozoa in the uterus and oviducts in twelve gilts was determined 1 and $4 \mathrm{hr}$, respectively, after insemination of $10^{10}$ deep-frozen spermatozoa thawed in seminal plasma or in TESNaK-glucose buffer. The numbers found in the oviducts $4 \mathrm{hr}$ after insemination were markedly higher when the spermatozoa were thawed in seminal plasma. Different theories are advanced concerning the mode of action of the seminal plasma in this respect.
\end{abstract}

A normal fertilization rate was reported by Polge, Salamon \& Wilmut (1970) for boar spermatozoa after deep freezing followed by deposition of the thawed spermatozoa directly into the oviducts by surgery. No fertilization took place when insemination was performed by way of the cervix, a finding which is in agreement with the those of Crabo \& Einarsson (1971) and Crabo, Einarsson, Lamm, Soosalu \& Viring (1972) when using TESNaK (Crabo, Brown \& Graham, 1972) -glucose buffer as thawing fluid. Satisfactory conception rates, however, were obtained by Crabo \& Einarsson (1971), by Crabo, Einarsson, Lamm, Soosalu \& Viring (1972) and by Einarsson, Swenssou \& Viring (1972) on insemination by way of the cervix after thawing and dilution of the deepfrozen spermatozoa in boar seminal plasma. From these results, it is evident that some factor in the seminal plasma is of importance for conception after insemination with deep-frozen spermatozoa. To elucidate whether the seminal plasma affects the transport of spermatozoa and/or is of significance for the fertility of frozen spermatozoa, the following experiment was performed.

Twelve sexually mature gilts were used and the onset of oestrus was taken as the time at which the gilts first stood to permit a boar (with hypoplastic testicles) to mount. The gilts were allocated to four experimental groups, A, B, C and D. Each gilt was inseminated once about $24 \mathrm{hr}$ after the onset of oestrus. All gilts were inseminated with $10^{10}$ spermatozoa collected from two fertile boars and deep frozen by the method described by Crabo \& Einarsson (1971) and by Crabo, Einarsson, Lamm, Soosalu \& Viring (1972). Thawing of frozen spermatozoa was performed in $70 \mathrm{ml}$ fresh seminal plasma obtained from a boar with totally hypoplastic testicles, or in $70 \mathrm{ml}$ TESNaK-glucose buffer 
(TESNaK buffer with $10 \%$ isotonic glucose). Sperm motility after thawing was about $30 \%$ ( 25 to $40 \%$ ).

Group A: three gilts were inseminated with frozen spermatozoa thawed in seminal plasma. The gilts were slaughtered $1 \mathrm{hr}$ after insemination.

Group B: three gilts were inseminated with frozen spermatozoa thawed in TESNaK-glucose buffer. The gilts were slaughtered $1 \mathrm{hr}$ after insemination.

Group C: three gilts were inseminated with frozen spermatozoa thawed in seminal plasma. The gilts were slaughtered $4 \mathrm{hr}$ after insemination.

Group D: three gilts were inseminated with frozen spermatozoa thawed in TESNaK-glucose buffer. The gilts were slaughtered $4 \mathrm{hr}$ after insemination.

Immediately after slaughter, the reproductive organs were removed. Clamps were placed in various positions, dividing the oviducts into two approximately equal parts and each uterine horn into three parts, the length of the anterior part being $5 \mathrm{~cm}$ and the other two being of equal size. Each region was flushed

Table 1. Recovery of spermatozoa from the reproductive tracts of gilts $1 \mathrm{hr}$ after insemination of frozen-thawed spermatozoa

\begin{tabular}{|c|c|c|}
\hline \multirow{2}{*}{ Segment of reproductive tract } & \multicolumn{2}{|c|}{ Mean number of spermatozoa recovered $\left(\times 10^{6}\right) \pm S . E$} \\
\hline & Group $A$ & Group B \\
\hline $\begin{array}{l}\text { Uterine horns (right and left) } \\
\text { Posterior part } \\
\text { Middle part } \\
\text { Anterior part }(5 \mathrm{~cm})\end{array}$ & $\begin{array}{r}423 \cdot 700 \pm 225 \cdot 600 \\
310 \cdot 500 \pm 96 \cdot 800 \\
31 \cdot 000 \pm 23 \cdot 600\end{array}$ & $\begin{array}{r}1303 \cdot 700 \pm 730 \cdot 500 \\
1268 \cdot 800 \pm 609 \cdot 000 \\
55 \cdot 600 \pm 15 \cdot 500\end{array}$ \\
\hline $\begin{array}{l}\text { Oviducts (right and left) } \\
\text { Posterior half } \\
\text { Anterior half }\end{array}$ & $\begin{array}{ll}0.020 \pm & 0.010 \\
0.150 \pm & 0.130\end{array}$ & $\begin{array}{ll}0.150 \pm & 0 \cdot 130 \\
0.140 \pm & 0.130\end{array}$ \\
\hline $\begin{array}{l}\text { Ratio between numbers of spermatozoa } \\
\text { found in oviducts and in anterior } 5 \mathrm{~cm} \text { of } \\
\text { uterine horns }\end{array}$ & $0.010 \pm \quad 0.006$ & $0.005 \pm 0.004$ \\
\hline
\end{tabular}

Spermatozoa were thawed in seminal plasma (Group A) or in TESNaK-glucose buffer (Group B). Each group contained three gilts.

with a measured volume of isotonic saline. The washings from the oviducts were concentrated $1: 5$ by centrifugation before counts were carried out. The sperm concentration was determined in a Bürker haemocytometer. The total number of spermatozoa in each region was calculated.

The results are presented in Tables 1 and 2. There was no significant difference in the number of spermatozoa recovered from the oviducts of gilts in Groups A and B (Table 1). The distribution of spermatozoa within the uterine parts was also approximately the same but, on average, more spermatozoa were recovered from the uterine parts of the gilts in Group B. The ratio between the numbers of spermatozoa recovered from the oviducts and from the anterior $5 \mathrm{~cm}$ of the uterine horns was somewhat lower for gilts in Group B than in Group A. The number of spermatozoa found in the oviducts $4 \mathrm{hr}$ after insemination was markedly lower when the spermatozoa were thawed in TESNaK-glucose buffer than when they were thawed in seminal plasma (Table 2). The very low 
numbers of spermatozoa found in the oviducts of the gilts in Group D are in agreement with the findings of Schefels, Biegert \& Leidl (1971). In the uterine horns too, except for the anterior $5 \mathrm{~cm}$, the numbers of spermatozoa found were markedly lower for gilts belonging to Group D than to Group C. The ratio between the numbers of spermatozoa found in the oviducts and in the anterior $5 \mathrm{~cm}$ of uterine horns was lower for gilts in Group D than in Group C.

Deep-frozen spermatozoa thawed in TESNaK-glucose buffer disappeared more rapidly and thus appear to survive for a shorter time in the uterus than spermatozoa thawed in seminal plasma. This may correlate with the observations by Bedford (1965) that damaged or dead spermatozoa disappear more rapidly from the uterus by phagocytosis than intact spermatozoa. A difference in survival time was also found in in-vitro studies of deep-frozen boar spermatozoa thawed in TESNaK-glucose buffer and in seminal plasma, respectively, and preserved at $37^{\circ} \mathrm{C}$ for at least $4 \mathrm{hr}$ (Einarsson, Soosalu, Swenssou \& Viring,

Table 2. Recovery of spermatozoa from the reproductive tracts of gilts $4 \mathrm{hr}$ after insemination of frozen-thawed spermatozoa

\begin{tabular}{|c|c|c|c|}
\hline \multirow{2}{*}{ Segment of reproductive tract } & \multicolumn{3}{|c|}{ Mean number of spermatozoa recovered $\left(\times 10^{6}\right) \pm S . E$. } \\
\hline & Group $C$ & Group & \\
\hline $\begin{array}{l}\text { Uterine horns (right and left) } \\
\text { Posterior part } \\
\text { Middle part } \\
\text { Anterior part }(5 \mathrm{~cm})\end{array}$ & $\begin{array}{r}269 \cdot 600 \pm 268 \cdot 500 \\
25 \cdot 800 \pm 25 \cdot 400 \\
0 \cdot 300 \pm \quad 0 \cdot 100\end{array}$ & $\begin{array}{l}7 \cdot 400 \pm \\
0 \cdot 200 \pm \\
0 \cdot 100 \pm\end{array}$ & $\begin{array}{l}7 \cdot 400 \\
0.200 \\
0.040\end{array}$ \\
\hline $\begin{array}{l}\text { Oviducts (right and left) } \\
\text { Posterior half } \\
\text { Anterior half }\end{array}$ & $\begin{array}{ll}0.020 \pm & 0.001 \\
0.030 \pm & 0.030\end{array}$ & $0.004 \pm$ & 0.001 \\
\hline $\begin{array}{l}\text { Ratio between numbers of spermatozoa } \\
\text { found in oviducts and in anterior } 5 \mathrm{~cm} \text { of } \\
\text { uterine horns }\end{array}$ & $0.148 \pm 0.061$ & $0.056 \pm$ & 0.028 \\
\hline
\end{tabular}

Spermatozoa were thawed in seminal plasma (Group C) or in TESNaK-glucose buffer (Group D). Each group contained three gilts.

1972). Obviously, some factor in the seminal plasma is of significance for the survival and fertility of deep-frozen spermatozoa during and after thawing and dilution. The possible contribution of substances of a protein nature in the seminal plasma to the maintenance of the motility and fertilizing capacity. of the spermatozoa is being studied.

Labelled albumin, suspended in boar seminal plasma, remains attached to the surface of ejaculated boar spermatozoa (Einarsson, 1971). The mode of action of the seminal plasma protein, therefore, might be to give the spermatozoa a protective coating during thawing and dilution.

When an adequate volume of semen is inseminated into gilts, the number of spermatozoa reaching the oviducts depends on the sperm concentration (Baker, Dziuk \& Norton, 1968). Rigby (1966) found a direct correlation between the number of spermatozoa at the uterotubal junction and the number of spermatozoa in the corresponding oviduct. In the present study, the ratio 
between the number of spermatozoa found in the oviducts and in the anterior $5 \mathrm{~cm}$ of the uterine horns was lower for gilts belonging to Groups $B$ and $D$ than for gilts in groups A and C. This might be due to a higher percentage of dead spermatozoa in the anterior $5 \mathrm{~cm}$ of uterine horns in the former groups. Although the initial transport of dead spermatozoa into the oviducts is as rapid as that of live spermatozoa (First, Short, Peters \& Stratman, 1968), it has been established that fewer dead spermatozoa enter the oviducts (Baker \& Degen, 1972).

Another possibility is that the seminal plasma itself affects the transport of spermatozoa into the oviducts. The effect of boar seminal plasma on uterine motility has been studied (Chury, Kozumplik \& Simunek, 1968; Zerobin, 1968), but there appears to be no published report concerning the effect on sperm transport into the oviducts of female swine.

This work was supported by The Swedish Council for Forestry and Agricultural Research (A 3140/ B 2340).

\section{REFERENGES}

BAKER, R. D. \& Degen, A. A. (1972) Transport of live and dead boar spermatozoa within the reproductive tract of gilts. F. Reprod. Fert. 28, 369.

Baker, R. D., Dziuk, P. J. \& Norton, H. W. (1968) Effect of volume of semen, number of sperm and drugs on transport of sperm in artificially inseminated gilts. F. Anim. Sci. 27, 88.

BEDFord, J. M. (1965) Effect of environment on phagocytes of rabbit spermatozoa. F. Reprod. Fert. 9, 249.

Chury, J., Kozumplix, J. \& Simunex, J. (1968) The relation between fertility and the effect of semen on uterine tonicity. Anim. Breed. Abstr. 36, 1733.

Grabo, B., Brown, K. I. \& Graham, E. F. (1972) Effect of some buffers on storage and freezing of boar spermatozoa. 7. Anim. Sci. 35, 377.

Grabo, B. \& Einarsson, S. (1971) Fertility of deep frozen spermatozoa. Acta vet. scand. 12, 125.

Crabo, B., Einarsson, S., Lamm, A.-M., Soosalu, O. \& Viring, S. (1972) Studies on the fertility of deep frozen spermatozoa. Proc. VIIth Int. Congr. Amin. Reprod., München 1972, (in press).

Einarsson, S. (1971) Studies on the composition of epididymal content and semen in the boar. Acta vet. scand. 12, Suppl. 36.

Einarsson, S., Soosalu, O., Swenssou, T. \& Viring, S. (1972) On the fertility and survival of deep frozen boar spermatozoa thawed in skim milk. Acta vet. scand. 13, 446.

First, N. L., Short, R. E., Peters, J. B. \& Stratman, F. W. (1968) Transport and loss of boar spermatozoa in the reproductive tract of the sow. F. Anim. Sci. 27, 1037.

Polge, G., Salamon, S. \& Wilmut, I. (1970) Fertilizing capacity of frozen boar semen following surgical insemination. Vet. Rec. 87, 424.

Rigby, J. P. (1966) The persistence of spermatozoa at the uterotubal junction of the sow. F. Reprod. Fert. 11, 153.

Scherels, W., Begert, W. \& LeidL, W. (1971) Die Verteilung der Spermien im weiblichen Genitale des Schweines nach Insemination von frischen und tiefgefrorenem Sperma. Zuchthyg. 6, 60.-

ZERoBin, K. (1968) Untersuchungen über die Uterusmotorik des Schweines. Zentbl. Vet Med. A, 15, 740. 